\title{
2110
}

\section{小形ギヤードモータ用歯車減速機の損失評価* (グリースの与える影響の実験的検証)}

\section{Loss Evaluation of Small Sized Gear Reducer for Electric Motor (Experimental Verification of Influence of Grease)} \\ Yoichi MATSUMOTO*2 and Haruo HOUJOH \\ ${ }^{* 2}$ ORIENTAL MOTOR CO., LTD. \\ Higashiueno 2-1-11, Taito-ku, Tokyo, 110-0015 Japan
}

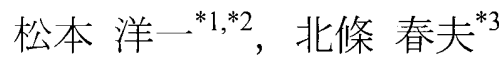

In this paper, we evaluated the difference in the grease of a small sized geared motor, which was kind and kinematic viscosity of base oil and cone penetration. The result shows that, the loss at no loading depends on the cone penetration and the kinematic viscosity of base oil. Load depending part, the friction loss of gear mesh not depends on the cone penetration and the kinematic viscosity of base oil. The mean friction coefficient of a tooth flank by grease lubrication proved the constant value that mineral base oil type was 0.09 to 0.11 , and synthetic base oil type was 0.07 to 0.08 .

Key Words : Gear, Electronic Equipment, Loss, Measurement, Grease, Geared motor, Lubrication

\section{1. 緒言}

本研究は，小形ギヤードモータで一般的な多段平行軸歯車減速機を対象に，損失を要因ごとに明らかにして， 今後の損失低減の指針を示すことを目的に進めている。筆者らは，前報 (1) で小形ギヤードモータの損失要因を実 験的に分析し，無負荷時はグリースによる損失，負荷時は歯面のかみ合い摩擦損失の割合が高いことを明らかに した．今までの研究から，小形ギヤードモータは無負荷時と負荷時ともに，グリースが影響する損失の割合が高 く，損失低減にはグリースが重要な要素であると言える.

本論文では, グリースのちょう度, 基油の種類と動粘度が損失に与える影響を実験的に検討し, 明らかにして いる.

\section{2. 実験装置，試験減速機と分析方法}

本実験で使用した実験装置と試験ギヤードモータは，前報 ${ }^{(1)}$ と同じなので，ここでは概要のみを示す．

\section{$2 \cdot 1$ 実験装置と試験ギヤードモータ}

実験装置は, 動力吸収型のギヤードモータ試験機を使用した。この装置は, 可変速交流モータからの動力が, 入力軸側トルク計, 試験ギヤードモータ, 出力軸側トルク計を介して, ヒステリシスブレーキで吸収される.

実験で用いたギヤードモータは, モータ部が定格出力 $90 \mathrm{~W}$ のコンデンサー形の単相誘導モータ, 減速機部が減 速比 9 で定格トルク $5 \mathrm{Nm}$ の 2 段平行軸歯車減速機である. 本研究は, 減速機部にモータ軸を含めたギヤードモ 一タ全体の機械的損失の評価を行う。試験ギヤードモータの構造を図 1，歯車諸元を表 1 に示寸.

\footnotetext{
* 原稿受付 2013 年 09 月 12 日

*1 正員, 東京工業大学 大学院総合理工学研究科 メカノマイクロ工学専攻（†226-8503 神奈川県横浜市緑区長津田町 4259）

*2 オリエンタルモーター株式会社（产110-0015 東京都台東区東上野 2-1-11）

*3 正員, フェロー, 東京工業大学 精密工学研究所（†226-8503 神奈川県横浜市緑区長津田町 4259）

E-mail: ymatsu@orientalmotor.co.jp
} 


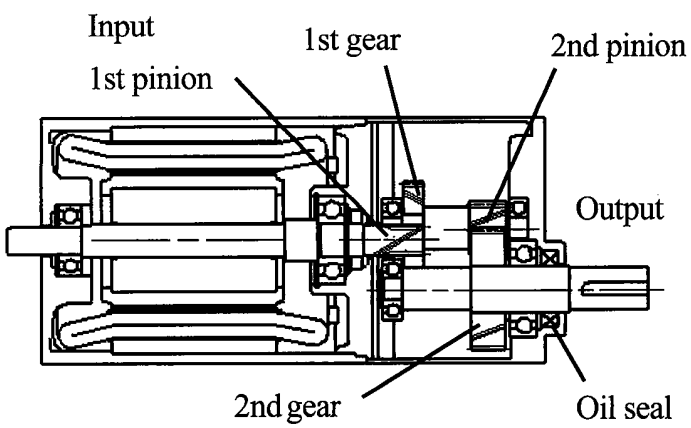

\begin{tabular}{|c|c|c|c|c|}
\hline & \multicolumn{2}{|c|}{$1^{\text {st }}$ stage } & \multicolumn{2}{|c|}{$2^{\text {nd }}$ stage } \\
\hline & Pinion & Gear & Pinion & Gear \\
\hline Normal module $\quad(\mathrm{mm})$ & \multicolumn{2}{|c|}{0.8} & \multicolumn{2}{|c|}{0.8} \\
\hline Normal pressure angle ${ }^{\circ}$ ) & \multicolumn{2}{|c|}{20} & \multicolumn{2}{|c|}{20} \\
\hline Helix angle $\quad($ ) & \multicolumn{2}{|c|}{30} & \multicolumn{2}{|c|}{20} \\
\hline Number of teeth & 10 & 36 & 20 & 50 \\
\hline Center distance & \multicolumn{2}{|c|}{21.37} & \multicolumn{2}{|c|}{30.49} \\
\hline
\end{tabular}

Fig. 1 Test geared motor

\section{$2 \cdot 2$ 試験グリース}

試験グリースは，ちょう度，基油の動粘度とその種類が異なる，表 2 に示す 7 種類とした．小形ギヤードモー 夕の平行軸歯車の潤滑は，ちょう度番号が 2 号 000 号，基油の動粘度が $100 \sim 200 \mathrm{~mm}^{2} / \mathrm{s}\left(40^{\circ} \mathrm{C}\right)$ のグリースが多 く使われるため, これらの範囲を基準に市販品から選定した.

Table 2 Properties of grease

\begin{tabular}{l||c|c|c|c|c|c|c}
\hline \hline Grease type & MA-2 & MA-1 & MA-0 & MB-1 & MC-000 & S-2 & S-1 \\
\hline \hline Thickener & \multicolumn{2}{|c|}{ Lithium } & Lithium & Lithium & Aluminum complex \\
\hline Base oil type & \multicolumn{3}{|c|}{ Mineral } & Mineral & Mineral & \multicolumn{2}{c|}{ Synthetic } \\
\hline Base oil viscosity & \multicolumn{3}{|c|}{156 at $40^{\circ} \mathrm{C}$} & 400 at $40^{\circ} \mathrm{C}$ & 296 at $40^{\circ} \mathrm{C}$ & \multicolumn{2}{c|}{17.5 at $40^{\circ} \mathrm{C}$} \\
$\left(\mathrm{mm}^{2} / \mathrm{s}\right)$ & \multicolumn{3}{|c|}{14.2 at $100^{\circ} \mathrm{C}$} & 32 at $100^{\circ} \mathrm{C}$ & 18 at $100^{\circ} \mathrm{C}$ & 3.2 at $100^{\circ} \mathrm{C}$ \\
\hline NLGI consistency class & 2 & 1 & 0 & 1 & 000 & 2 & 1 \\
\hline \hline
\end{tabular}

\section{$2 \cdot 3$ 損失の分析方法}

グリース潤滑される平行軸歯車減速機の損失は，負荷時の全体の損失と無負荷時の損失に分けると式(1)，(2) のように表すことができる(1)

$$
\begin{aligned}
& L_{T}=L_{O}+L_{B}+L_{M}+\Delta L_{O G} \\
& L_{O}=L_{O S}+L_{O G B}+L_{O G M}
\end{aligned}
$$

ここで， $L_{T}$ は全損失トルク， $L_{O}$ は無負荷時の損失トルク， $L_{B}$ は軸受の摩擦損失トルク $L_{M}$ は歯面のかみ合 い摩擦損失トルク， $L_{O S}$ はオイルシールの摩擦損失トルク， $L_{O G B}$ は軸受のグリースによる損失トルク， $L_{O G M}$ は 歯面のグリースによる損失トルク， $\Delta L_{O G}$ はグリースによる損失の温度変化を示す.

損失の分析は, 前報 (1) で得られたオイルシールの損失, 軸受けのグリースによる損失, 軸受けの摩擦係数の值 を用いて行う. 歯面の平均摩擦係数は, 歯面の摩擦損失トルクから Niemann ${ }^{(2)}$ の式により算出する.

\section{3. 実験結果と考察}

損失トルクの測定例として, 図 2 に歯面塗布の MA-1 グリースとグリースバスの MC-000 グリースの負荷トル クと損失トルクの関係を示す．ともに無負荷時の一定量の損失があり，負荷トルクを加えると損失トルクは，ほ ぼ線形に増加している．また歯面塗布の MA-1 グリースでは速度依存性はほとんど認められないが，グリースバ スの MC-000 グリースでは，無負荷時の損失は回転速度とともに増加し，負荷トルクに依存する成分の傾きが速 度により異なる．この傾きの速度による違いは，減速機の温度を変化させた別の実験により，グリースによる損 失の温度変化分だと分かった。 


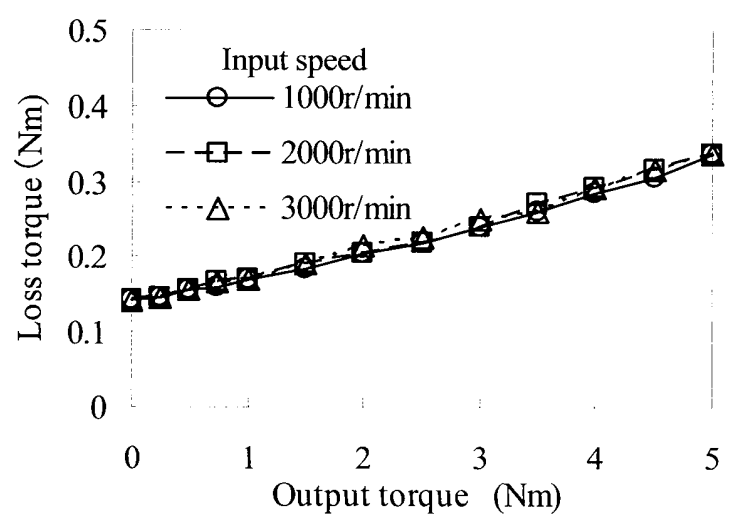

(a) Grease type MA-1 of application on tooth flank

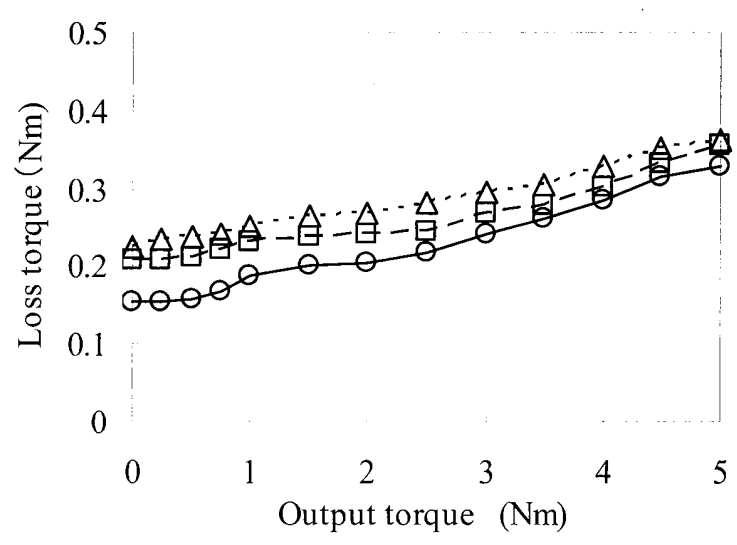

(b) Grease type MC-000 of soaking in grease

Fig. 2 Total loss torque vs. output torque

損失の分析により得られた歯面の摩擦損失トルクを線形近似して求めた歯面の平均摩擦係数 $\left(\mu_{m G}\right)$ を, まとめて 図 3 に示す．グリース名の添え字の-A が歯面塗布，-S がグリースバスを示す，歯面の平均摩擦係数は，ちょう度 番号 000 号の歯面塗布を除くと鉱油系が $\mu_{m G}=0.09 \sim 0.11$ ，合成油が $\mu_{m G}=0.07 \sim 0.08$ であり，合成油の方が小さく なっており，従来の油潤滑の研究と同様の結果が得られた。また，歯面の平均摩擦係数が高い值で一定になるの は，本試験減速機の平均滑り速度は，0.03 0.31 $/ \mathrm{s}$ と低速で，潤滑される面に潤滑油が引き込まれる効果が小さ く，そのため油膜が薄くなったことと，グリース潤滑では歯面に供給される基油の量が少ないためと考える.

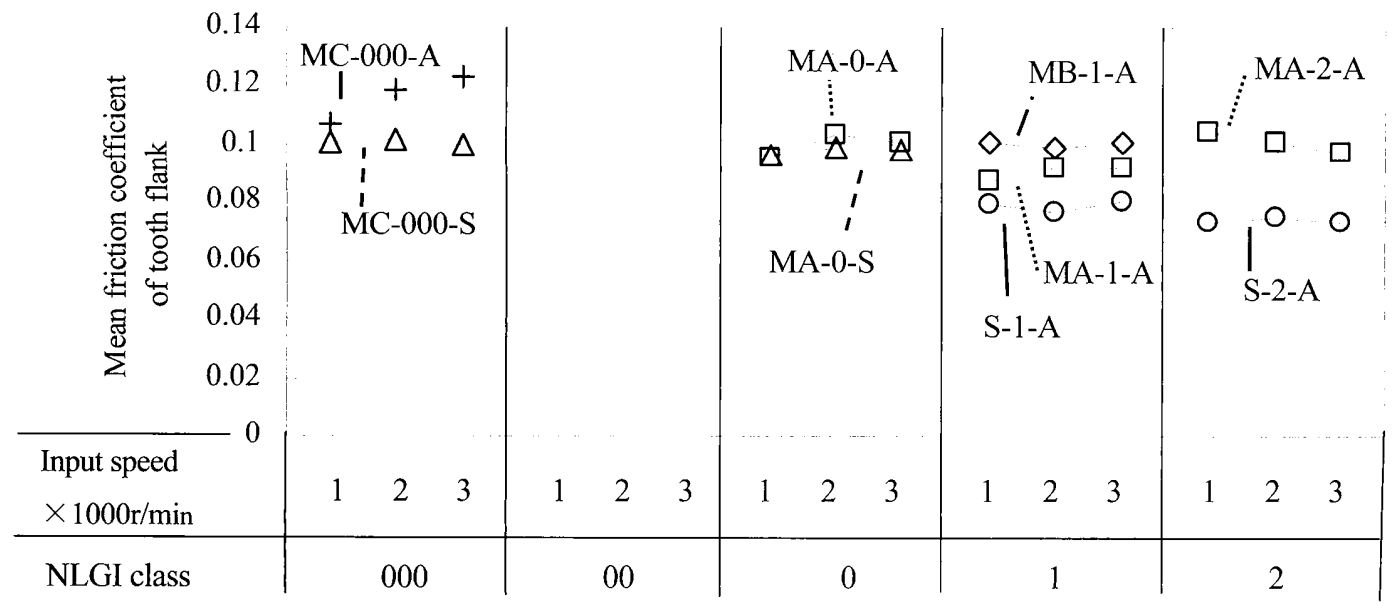

Fig. 3 Mean friction coefficient of tooth flank by liner approximation

\section{5. 結言}

小形ギヤードモータのグリースによる損失の違いを実験的に検討した結果，以下の結論を得た.

1. 歯面の摩擦損失トルクほ, 負荷トルクに対してほぼ線形に増加し, 歯面の平均摩擦係数を一定值に近似でき る。また速度依存性もほとんど認められない。

2. 線形近似した歯面の平均摩擦係数は，基油が鉱油で $\mu_{m G}=0.09 \sim 0.11$, 基油が合成油で $\mu_{m G}=0.07 \sim 0.08$ だった. また基油の動粘度とグリースのちょう度にはほとんど影響されない。

\section{文献}

(1) 松本洋一, 北條晴夫 “小形ギヤードモータ用歯車減速機の損失要因の分析（ちょう度 2 号のグリース潤滑におけ る実験的推定)”，日本機械学会論文集 C 編，Vol. 78, No. 786 (2012), pp.627-638.

(2) $\mathrm{G}$ 二ーマン原著, 成瀬長太郎訳, 機械要素 動力伝達編, 初版(1971), pp. 60-66, 養賢堂. 